\title{
Long-term laboratory observations of Euphausia pacifica fecundity: comparison of two geographic regions
}

\author{
Leah R. Feinberg ${ }^{1, *}$, C. Tracy Shaw ${ }^{1}$, William T. Peterson ${ }^{2}$ \\ ${ }^{1}$ Cooperative Institute for Marine Resources Studies, and ${ }^{2}$ NOAA/NMFS, \\ Hatfield Marine Science Center, 2030 S. Marine Science Drive, Newport, Oregon 97365, USA
}

\begin{abstract}
We tested the assumption that female Euphausia pacifica produce multiple broods of eggs during their spawning season by maintaining individual females under laboratory conditions at $10.5^{\circ} \mathrm{C}$ and comparing the egg production of females collected from 2 populations, 1 from Heceta Bank off central Oregon $\left(44^{\circ} \mathrm{N}, \mathrm{n}=27\right.$ individuals), and the other from waters near Santa Barbara, California $\left(34^{\circ} \mathrm{N}, \mathrm{n}=12\right.$ individuals). We documented the production of multiple, distinct broods by daily observation of females over periods from 1 to 9 mo. Median brood sizes were not significantly different between regions: 102 eggs for females from Heceta Bank and 116 eggs for females from Santa Barbara. Median interbrood period (IBP) was significantly different: $4 \mathrm{~d}$ for Santa Barbara females and $5 \mathrm{~d}$ for Heceta Bank females. Brood size and IBP were highly variable within and among individuals. The total number of eggs produced female ${ }^{-1}$ in the experiment ranged from 378 to 8600 , and IBPs ranged from 1 to $79 \mathrm{~d}$. A brood of eggs represented an average of $9 \%$ of the female's weight in carbon, equivalent to 0.5 to $6 \%$ of body weight $\mathrm{d}^{-1}$ (average of $1.7 \% \mathrm{~d}^{-1}$ ).
\end{abstract}

KEY WORDS: Euphausia pacifica $\cdot$ Fecundity $\cdot$ Interbrood period $\cdot$ Brood size

\section{INTRODUCTION}

Among the macrozooplankton and micronekton, Euphausia pacifica is one of the most important secondary producers in the California Current system, as well as many other areas of the north Pacific (Brinton 1962). E. pacifica is a broadcast spawner, and though it is assumed that it releases multiple broods during a spawning season (Ross et al. 1982), there is little direct evidence. As a result, there are no reliable estimates of fecundity for this species. Fecundity calculations require 3 pieces of information: brood size, interbrood period (IBP), and duration of the spawning season. In previous studies, brood sizes for E. pacifica have been estimated directly by counting the eggs released by an incubated female (Ross et al. 1982, Iguchi \& Ikeda 1994, Gómez Gutiérrez et al. 2006, Pinchuk \& Hopcroft 2006) and indirectly by counting the number of ripe eggs in the ovaries of preserved females (Ponomareva 1966, Mauchline \& Fisher 1969, Brinton 1976). Counting the number of eggs in the ovaries can result in brood size estimates that may be artificially high or low, because (1) the rate of maturity from one egg stage to the next is unknown, and (2) a female may not release all mature eggs as a single brood.

The second component of fecundity, IBP, has rarely been directly measured in the laboratory for Euphausia pacifica. Using 4 females from the Gulf of Alaska, Pinchuk \& Hopcroft (2006) found that the average IBP was $8 \mathrm{~d}$ at $12^{\circ} \mathrm{C}$, with a range of 2 to $36 \mathrm{~d}$. IBP has been estimated for this species in past studies by using the inverse of the proportion of ripe females in the population (Ross et al. 1982). Ross et al. (1982) defined ripe females as those whose ovaries had turned purple during an incubation and who produced eggs within $24 \mathrm{~h}$. They esti- 
mated IBP to be from 2 to $10 \mathrm{~d}$ for females from Puget Sound, Washington, depending on season and animal size. Gómez-Gutiérrez (2003) used preserved samples and counted the number of females with mature eggs in their ovaries, assuming that the eggs would have been released within $24 \mathrm{~h}$, and then used an inverse proportion to determine IBP. However, this method is not always a good indication of IBP, because there is no assurance that a mature egg would have been released within 24 h. In fact, Ross et al. (1982) found approximately half as many ripe females (spawning within $24 \mathrm{~h}$ ) as females with mature eggs in their ovaries in a population from Port Susan, Puget Sound, Washington. This implies that mature eggs might be released within $48 \mathrm{~h}$ rather than $24 \mathrm{~h}$, a change in assumptions that would double calculated IBPs.

The duration of the spawning season is the third factor that determines fecundity. The spawning season is likely a function of the length of the seasonal cycle of primary production. The duration of the spawning season for Euphausia pacifica appears to vary by location, from 2 mo in Puget Sound (Ross et al. 1982), to 6 mo in the upwelling zone off Oregon (Feinberg \& Peterson 2003), to year-round off southern California (Brinton 1976).

The experiments described in this study are a part of a GLOBEC Northeast Pacific study of euphausiid population dynamics. These long-term studies provide direct measurements of brood size, IBP, and fecundity on a daily basis in the laboratory, as well as simultaneous measurements of molting and growth rates. Our daily measurements also allowed for observation of variability in spawning patterns among individuals and between 2 populations of Euphausia pacifica. Previous studies have shown interannual differences in brood sizes and the length of spawning seasons in different geographical areas (Feinberg \& Peterson 2003, Gómez-Gutiérrez et al. 2006). By bringing animals into a controlled laboratory setting, we hoped to determine whether there were population-level differences in spawning patterns and fecundity.

In this study, we observed Euphausia pacifica females collected in the coastal upwelling zone of the Pacific Ocean off Santa Barbara, California, and Heceta Bank, Oregon, with the following objectives: to determine (1) whether E. pacifica produce multiple broods, (2) whether females with purple ovaries will spawn within $24 \mathrm{~h}$, (3) whether there is a difference in fecundity between 2 geographically separated populations when maintained under the same conditions, (4) whether females will follow predictable patterns of spawning, (5) whether there is a predictable relationship between growth and reproductive effort, and (6) whether the investment in reproduction is equal to, less than, or greater than female growth.

\section{MATERIALS AND METHODS}

Collection of animals. Santa Barbara (SB) females were collected from the Santa Barbara Channel $\left(34^{\circ} 21^{\prime} \mathrm{N}, 119^{\circ} 59^{\prime} \mathrm{W}\right.$, station depth $530 \mathrm{~m}$ ) at night on 31 March 2003 with a $333 \mu \mathrm{m}, 1 \mathrm{~m}$ diameter net towed obliquely to a depth of $20 \mathrm{~m}$. Adults were sorted into $2.5 \mathrm{l}$ jars and shipped overnight on ice to our laboratory in Newport, Oregon, arriving on 2 April 2003. Heceta Bank (HB) females were collected at night from a station (HH05) in $930 \mathrm{~m}$ of water just west of Heceta Bank off the central Oregon coast $\left(44^{\circ} \mathrm{N}, 125^{\circ} \mathrm{W}\right)$. Animals were collected with a $333 \mu \mathrm{m}$ net towed obliquely from 60 to $30 \mathrm{~m}$ water depth on 8 July 2003. The animals were placed individually in 11 containers of filtered seawater and maintained at $10^{\circ} \mathrm{C}$ until they arrived at our laboratory in Newport later that day.

Laboratory experiments. We selected healthy-looking, mature female Euphausia pacifica from both locations. Mature females had visible thelyca and usually purple ovaries. 'Healthy looking' meant all appendages were visually intact and the animal was actively swimming. We endeavored to select individuals of similar size to avoid complications of brood size varying as a function of body size. The range in total length of the females was 18 to $22 \mathrm{~mm}$, with most individuals 20 to $21 \mathrm{~mm}$ at the start of the experiment (Table 1). Twelve mature females were selected from SB for an experiment that ran from April through December 2003. Twenty-seven mature females were incubated from HB for an experiment lasting from July through December 2003.

All animals were incubated individually in clear, 11 polycarbonate jars filled with filtered seawater. All animals were maintained in a walk-in cold room under the same water, temperature, light, and feeding conditions. They were kept in the dark at $10.5 \pm 0.5^{\circ} \mathrm{C}$. Every other day, females were fed a mixture of algal cultures at a combined concentration always exceeding $500 \mu \mathrm{g}$ carbon (C) $\mathrm{l}^{-1}$. Algae were grown in batch cultures at $16^{\circ} \mathrm{C}$ using a culture medium described by Matthiessen \& Toner (1966). The diet consisted of the diatoms Chaetoceros Calcitrans and Ditylum sp., the flagellates Rhodomonas salina and Tetraselmis chui, the autotrophic dinoflagellate Heterocapsa triquetra, and the heterotrophic dinoflagellate Oxyrrhis sp. Food concentrations were not monitored within any of the 39 containers, but daily observations of the coloration of the animals' guts showed that food was always present. Incubation water was sieved daily to remove eggs, molts, and fecal pellets and replaced every other day. Handling of females was minimal. Eggs were counted, and lengths of the molt telsons were measured with the aid of a dissecting microscope. Growth was estimated from the difference in length between 
Table 1. Euphausia pacifica. Summary statistics for females from Santa Barbara (SB) and Heceta Bank (HB). Average no. of eggs brood $^{-1}$ (Avg. brood) and average interbrood period (Avg. IBP) are the true numerical means of all broods and IBPs for each female, not calculated from information given in this table. Daily fecundity is the total number of eggs divided by the

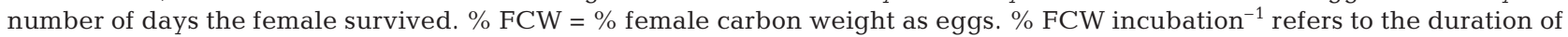
the experiment. $\mathrm{TL}=$ total length. Length measurements were not available for HB11

\begin{tabular}{|c|c|c|c|c|c|c|c|c|c|c|c|c|}
\hline Animal & $\begin{array}{l}\text { Broods } \\
\text { (no.) }\end{array}$ & $\begin{array}{l}\text { Total } \\
\text { eggs }\end{array}$ & $\begin{array}{c}\text { Avg. } \\
\text { brood }\end{array}$ & $\begin{array}{l}\text { Avg. } \\
\text { IBP }\end{array}$ & $\begin{array}{l}\text { Animal I } \\
\text { survival (d) }\end{array}$ & $\begin{array}{l}\text { Daily fecundity } \\
\text { ) (eggs) }\end{array}$ & $\begin{array}{c}\% \text { FCW } \\
\text { incubation }^{-1}\end{array}$ & $\begin{array}{c}\% \text { FCW } \\
\mathrm{d}^{-1}\end{array}$ & $\begin{array}{c}\text { Avg. } \% \\
\text { FCW } \text { brood }^{-1}\end{array}$ & $\begin{array}{c}\text { Avg. TL } \\
(\mathrm{mm})\end{array}$ & $\begin{array}{c}\text { Avg. C } \\
\text { (mg) }\end{array}$ & $\begin{array}{c}\text { Purple } \\
\text { ovaries (d) }\end{array}$ \\
\hline SB1 & 64 & 8597 & 126.4 & 3.5 & 262 & 32.8 & 596.7 & 2.6 & 8.9 & 19.26 & 4.6 & 115 \\
\hline SB2 & 40 & 5800 & 131.8 & 5.4 & 241 & 24.1 & 373.1 & 1.6 & 8.7 & 19.72 & 5 & 50 \\
\hline SB3 & 34 & 4263 & 125.3 & 7.1 & 260 & 16.4 & 298.3 & 1.2 & 9.4 & 19.22 & 4.6 & 102 \\
\hline SB4 & 17 & 2565 & 150.9 & 8.3 & 260 & 9.9 & 125.7 & 0.9 & 8.2 & 21.45 & 6.5 & 104 \\
\hline SB5 & 12 & 1601 & 133.1 & 20.4 & 260 & 6.2 & 101.1 & 0.4 & 7.5 & 19.83 & 5.1 & 223 \\
\hline HB1 & 30 & 2817 & 94.5 & 4.6 & 163 & 17.3 & 175.9 & 1.3 & 6.1 & 19.90 & 5.1 & 65 \\
\hline HB2 & 16 & 2522 & 154.8 & 7.8 & 149 & 16.9 & 180.9 & 1.4 & 11.6 & 19.07 & 4.5 & 105 \\
\hline HB3 & 10 & 1049 & 104.9 & 3.1 & 45 & 23.3 & 75.9 & 2.4 & 7.5 & 19.02 & 4.4 & 20 \\
\hline HB4 & 9 & 1205 & 133.9 & 12.9 & 163 & 7.4 & 65.2 & 0.6 & 7.5 & 20.80 & 5.9 & 13 \\
\hline HB5 & 14 & 1899 & 135.6 & 7.3 & 163 & 11.7 & 112.1 & 1.1 & 8.9 & 20.25 & 5.4 & 138 \\
\hline HB6 & 6 & 1372 & 228.7 & 2.8 & 34 & 40.4 & 72.5 & 4.4 & 8.7 & 20.94 & 6.1 & 11 \\
\hline HB7 & 4 & 2119 & 529.8 & 8.7 & 33 & 64.2 & 180.3 & 5.2 & 45.1 & 18.09 & 3.8 & 27 \\
\hline HB8 & 3 & 378 & 126.0 & 32.7 & 145 & 2.6 & 25.7 & 0.3 & 6.3 & 19.39 & 4.7 & 79 \\
\hline HB9 & 3 & 521 & 173.7 & 11.0 & 154 & 3.4 & 32.0 & 1.0 & 10.4 & 20.01 & 5.2 & 69 \\
\hline HB10 & 4 & 540 & 135.0 & 8.0 & 29 & 18.6 & 30.4 & 0.9 & 7.5 & 20.56 & 5.7 & 10 \\
\hline HB11 & 7 & 1494 & 213.0 & 3.7 & 29 & 51.5 & na & na & na & na & na & 14 \\
\hline
\end{tabular}

subsequent molts. For all calculations of length, the telson of the molt was measured and converted to total length (TL) using the equation:

$$
\mathrm{TL}=5.426 \text { (telson length) }-0.9869
$$

derived from our own laboratory measurements $(\mathrm{n}=$ $\left.603, \mathrm{r}^{2}=0.96\right)$. TL represents the length $(\mathrm{mm})$ of the animal from the back of the eye to the posterior tip of the telson. Occasionally molts were damaged, and no measurement was possible; in these few cases, an average of the previous and following telson lengths was used for calculation of TL. TL (mm) was converted to dry weight (DW, mg) using the equation:

$$
\mathrm{DW}=\left(\mathrm{TL}^{3.239}\right) 0.000795
$$

This equation was derived from the TL and DW measurements of 215 Euphausia pacifica individuals in our laboratory $\left(r^{2}=0.99\right)$. Published values for adult $C \%$ of dry weight range from 38.1 to $45.1 \%$ (Lasker 1966, Ross 1982a, Iguchi \& Ikeda 1998). We assumed that C weight was $40 \%$ of the dry weight. On average, 1 egg (mean diameter $355 \mu \mathrm{m}$ ) $=0.0032 \mathrm{mg}$ C (GómezGutiérrez 2003, n = 100). From these data, we calculated percent of female body weight produced as egg $\mathrm{C}$ incubation ${ }^{-1}$ by dividing total egg $\mathrm{C}$ by average female C. In order to calculate the percentage of female body weight produced as egg $\mathrm{C} \mathrm{d}^{-1}$, we divided average $\mathrm{C}$ brood $^{-1}$ by average IBP and then divided the result by average female $\mathrm{C}$. We also calculated the average percent of female $\mathrm{C}$ as eggs brood ${ }^{-1}$.
Analysis. Usually a female that produced eggs on one day would not spawn again for several days, but occasionally eggs were collected on 2 consecutive days. Since we had no way of knowing when exactly in the past $24 \mathrm{~h}$ the eggs were spawned (i.e. they could have been released within minutes of removal of the previous day's eggs or perhaps 1 batch of eggs was produced over a period of several hours), we could not determine whether eggs present on 2 successive days represented 2 distinct spawning events. Consequently, eggs from 2 successive days were combined into 1 brood for the purpose of analysis of brood size. This occurred for approximately $10 \%$ of all broods. IBP was calculated as the number of days between broods. Thus, if a female spawned on Monday and then again on Wednesday, the IBP would be calculated as $2 \mathrm{~d}$. If eggs from 2 successive days were combined into 1 brood, the IBP was calculated as starting from the mid-point. For instance, if eggs were found on Sunday, Monday, and Wednesday, the IBP recorded would be $2.5 \mathrm{~d}$. In 1 instance, eggs were found on 3 successive days, with only a much smaller number on the second day. This is the only instance where an IBP of $1 \mathrm{~d}$ was calculated, since we assumed that there were 2 batches of eggs and the eggs on the second day belonged with 1 of the other batches. Brood size and IBP were not normally distributed (see Figs. 1 \& 2). To compare these 2 parameters between populations, we used the Mann-Whitney $U$-test and report median values for the purpose of describing the population parameters.

We used several different approaches to investigate the relationship between egg production and female 
growth. We first determined the duration of the spawning period, defined as the time from first to last brood, for each female (Table 2). We then calculated the change in female $\mathrm{C}$ from the beginning to the end of this period and divided it by the number of days in the spawning period to determine the change in female $\mathrm{C} \mathrm{d}^{-1}$. This was compared to the amount of $\mathrm{C}$ produced $\mathrm{d}^{-1}$ as eggs divided by the total length (d) of the spawning period (Table 2). These relationships were analyzed using linear regression. We performed these analyses on each group of females by population (SB and $\mathrm{HB}$ ) and then on all females combined. We also selected linear growth periods of at least 1 mo in duration (see Figs. 3-5) and compared growth to egg production for these shorter periods. Female length and eggs were converted to $\mathrm{mg} \mathrm{C}$, and the slopes of the lines (change in female $\mathrm{C} \mathrm{d}^{-1}$ ) were tested for correlation with the daily $\mathrm{C}$ invested in eggs during that period. These correlations were again carried out with linear regression for each group of females by population and then for all females combined.

\section{RESULTS}

In total, 39 ripe Euphausia pacifica females were incubated in these experiments, 12 from SB and 27 from HB. All females were of similar size with TL ranging from 18 to $21 \mathrm{~mm}$. Of the 12 females from SB, 6 produced multiple broods, 3 produced only single broods, and 3 never produced eggs. Of the HB females, 14 produced multiple broods, 6 produced only a single brood, and 7 never produced eggs. A few of the females that produced multiple broods (1 from SB and
3 from HB) only spawned twice. Thus, they were not used to calculate IBP and are not included in the Tables or in Figs. 3-5. However, they were included in brood size comparisons. Most of the females that did not produce eggs only survived for the first week of the experiments.

Of the females that produced more than 2 batches of eggs, females from SB produced from 1601 to 8597 eggs over the course of the 9 mo experiment, while HB females produced from 378 to 2817 over the 6 mo that they were incubated (Table 1). Brood sizes ranged from 3 to 495 eggs for SB females and 4 to 804 eggs for HB females (Fig. 1). The median brood size for females from SB was 116 eggs, and the median IBP for the $5 \mathrm{SB}$ females that produced more than 2 broods was $4 \mathrm{~d}$ (range 1-79 d, Fig. 2). The median brood size for females from HB was 102 eggs and the median IBP was $5 \mathrm{~d}$, for females producing more than 2 broods (range 2 to 64 d, Fig. 2). Brood size was not significantly different between populations, but there was a significant difference in IBP between populations (Mann-Whitney $U$-test, $\mathrm{p}=0.005)$.

\section{Individual variability in frequency and magnitude of brood production}

One female spawned regularly and often throughout the experiment (SB1; every $3.5 \mathrm{~d}$ ), 5 females produced eggs regularly but less often (SB2 and SB3, HB1 to HB3; every 4 to $7 \mathrm{~d}$ ). The remaining 8 females produced eggs at seemingly random times. SB4 produced eggs only after spending $2.5 \mathrm{mo}$ in the laboratory; HB5 produced eggs only after 5 mo in the laboratory. HB3,

Table 2. Euphausia pacifica. Growth and reproductive effort for females from Santa Barbara (SB) and Heceta Bank (HB). Duration of spawning is the number of days from the first to last time that a female spawned within the experiment. TL $=$ total length. Female HB11 was not included in this table because there were not enough length measurements available for calculation of growth

\begin{tabular}{|c|c|c|c|c|c|c|c|c|c|c|}
\hline Animal & $\begin{array}{l}\text { Duration of } \\
\text { spawning (d) }\end{array}$ & $\begin{array}{l}\text { Starting } \\
\text { TL (mm) }\end{array}$ & $\begin{array}{l}\text { Change in } \\
\text { TL (mm) }\end{array}$ & $\begin{array}{l}\text { Change } \\
\text { in C (mg) }\end{array}$ & $\begin{array}{l}\text { Total } \\
\text { eggs }\end{array}$ & $\begin{array}{l}\text { Total egg } \\
\text { C (mg) }\end{array}$ & $\underset{\mathrm{d}^{-1}}{\text { Eggs }}$ & $\begin{array}{c}\text { Egg C } \\
\mathrm{d}^{-1}(\mathrm{mg})\end{array}$ & $\begin{array}{l}\text { Change in } \\
\text { female } \mathrm{C} \mathrm{d}^{-1}\end{array}$ & $\begin{array}{l}\% \text { change in } \\
\text { female } \mathrm{Cd}^{-1}\end{array}$ \\
\hline SB1 & 231 & 20.45 & -1.08 & -0.9 & 8597 & 27.5 & 37.2 & 0.12 & -0.004 & -0.08 \\
\hline SB2 & 219 & 20.23 & -1.07 & -0.9 & 5800 & 18.6 & 26.5 & 0.08 & -0.004 & -0.08 \\
\hline SB3 & 238 & 20.02 & -0.65 & -0.5 & 4263 & 13.6 & 17.9 & 0.06 & -0.002 & -0.05 \\
\hline SB4 & 135 & 20.87 & 1.08 & 1.1 & 2565 & 8.2 & 19.0 & 0.06 & 0.008 & 0.12 \\
\hline SB5 & 219 & 19.16 & 1.29 & 1.1 & 1601 & 5.1 & 7.3 & 0.02 & 0.005 & 0.10 \\
\hline HB1 & 158 & 21.52 & -1.72 & -1.6 & 2817 & 9.0 & 17.8 & 0.06 & -0.010 & -0.19 \\
\hline HB2 & 131 & 19.16 & 0.21 & 0.2 & 2522 & 8.1 & 19.3 & 0.06 & 0.001 & 0.03 \\
\hline HB3 & 39 & 21.95 & -0.57 & -0.4 & 1049 & 3.4 & 26.9 & 0.09 & -0.011 & -0.25 \\
\hline HB4 & 95 & 21.95 & -1.93 & -1.8 & 1205 & 3.9 & 12.7 & 0.04 & -0.019 & -0.32 \\
\hline HB5 & 162 & 21.73 & -2.36 & -2.1 & 1899 & 6.1 & 11.7 & 0.04 & -0.013 & -0.24 \\
\hline HB6 & 20 & 21.73 & -1.5 & -1.4 & 1372 & 4.4 & 68.6 & 0.22 & -0.070 & -1.15 \\
\hline HB7 & 32 & 19.0 & -1.0 & -0.7 & 2119 & 6.8 & 66.2 & 0.21 & -0.022 & -0.58 \\
\hline HB8 & 96 & 20.87 & -1.28 & -1.1 & 378 & 1.2 & 3.9 & 0.01 & -0.012 & -0.25 \\
\hline HB9 & 22 & 19.8 & 0.22 & 0.2 & 521 & 1.7 & 23.7 & 0.08 & 0.008 & 0.16 \\
\hline HB10 & 29 & 20.66 & -0.21 & -0.2 & 540 & 1.7 & 18.6 & 0.06 & -0.006 & -0.11 \\
\hline
\end{tabular}




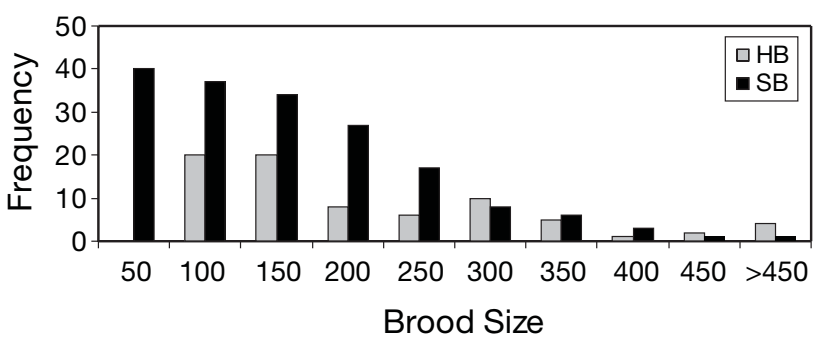

Fig. 1. Euphausia pacifica. Brood sizes of females from Santa Barbara (SB) and Heceta Bank (HB). No significant differences were found between SB and HB females

HB6, and HB7 produced eggs only during the first several weeks of the experiment and then died, whereas HB5 did not produce eggs regularly until the last 2 mo of the experiment. HB8 and HB9 were even more exceptional in that they had purple ovaries for most of the experiment but produced only 3 broods over 5.5 mo. Female HB7 was the most extreme individual, producing only 3 broods (and 2119 eggs) before her death. This is nearly the same output as the 2817 eggs produced by HB1 in 30 broods.

\section{Relationships between spawning and purple ovaries}

We found no clear pattern between the presence of a purple ovary and a spawning event (Figs. 3-5). This suggests that there may not be a regular, repeating cycle of the sequence: purple ovary $\rightarrow$ spawning event $\rightarrow$ non-colored ovary $\rightarrow$ purple ovary. The most extreme cases were females SB5 and HB5, both of which had continuously purple ovaries for more than $100 \mathrm{~d}$, during which time they produced only 3 broods each. We found that purple ovaries were followed by a spawning event within $24 \mathrm{~h}$ only $23 \%$ of the time for SB females and $11.4 \%$ of the time for HB females. Thus, having a purple ovary did not always mean that a female would spawn within the next $24 \mathrm{~h}$. However, females rarely spawned when their ovaries were not purple (only $6.5 \%$ of the time for SB and $11.6 \%$ of the time for HB females). Purple coloration may have been present in these cases, but of such short duration that it was not observed during daily monitoring of the females.

\section{Relationships between spawning and molting}

Females from both populations molted regularly with an average interval of $6 \mathrm{~d}$. Females from SB commonly spawned and molted within a $24 \mathrm{~h}$ period (55 to $71 \%$ of the broods, Table 3 ). The occasions when molting coincided with spawning were more variable,

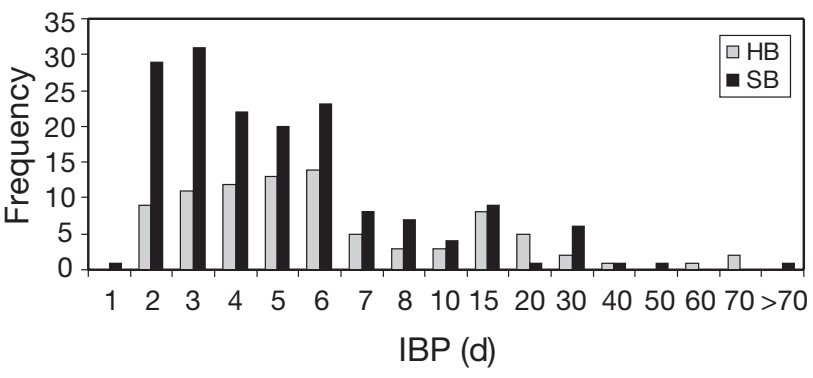

Fig. 2. Euphausia pacifica. IBP of females from SB and HB. SB females had significantly longer IBPs $(p=0.005)$. IBPs $>8 \mathrm{~d}$ were arbitrarily combined into bins of $>1 \mathrm{~d}$ duration

ranging from 20 to $86 \%$. This high variability was mostly due to periods when animals were molting but had not yet started to spawn (beginning of experiment) or were no longer spawning but were still molting (end of experiment). Most females spawned in conjunction with a molt, but those that produced the highest number of broods (i.e. Fig. 3; SB1 and SB2) often spawned between molting events as well, resulting in lower percentages of broods occurring with molts.

Females from HB did not show as clear a pattern between molting and spawning. The percentage of females from HB that spawned and molted within $24 \mathrm{~h}$ ranged from 27 to $100 \%$ (Table 3). Unlike the females from $\mathrm{SB}$, there was no clear pattern of association between molting and spawning among females with the highest or lowest number of broods during the experiment.

\section{Relationships between spawning and growth}

Growth patterns of individual females varied widely throughout the experiment (Figs. 3-5). We compared the difference in female $\mathrm{C}$ between the start and the end of each female's spawning period and found that 3 of the $5 \mathrm{SB}$ females and 8 of the $10 \mathrm{HB}$ females lost weight during their spawning period (Table 2). Overall, females with the highest egg production lost the most weight (Table 2, Fig. 6). SB and HB females both had negative relationships between egg production and growth, although egg production only explained $46 \%$ and $29 \%$ of the variability in growth for the SB and HB females, respectively. This negative relationship was still evident when all females were combined for analysis, but only explained $45 \%$ of the variability (Fig. 6).

Most females went through periods of both growth and shrinkage during the course of the experiment (Figs. 3-5). Thus, in addition to calculating the net change in $\mathrm{C}$ over the course of the entire experiment, we also compared female growth to egg production 


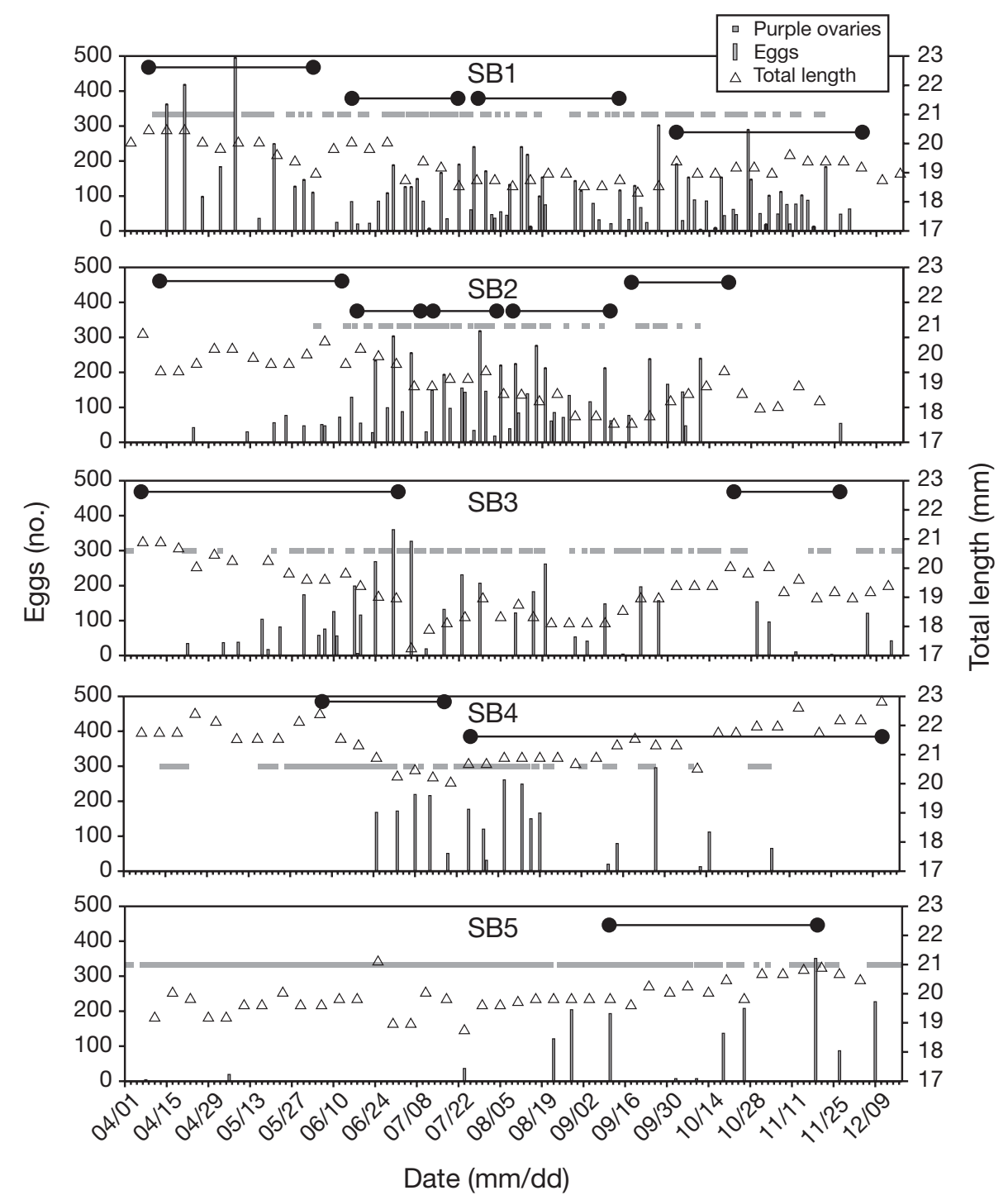

Fig. 3. Euphausia pacifica. Spawning and growth of individual SB females. Vertical bars: date and size of each brood. Triangles: total length (TL) of the female each time she molted. Gray horizontal bars indicate when the ovary showed purple coloration. Black lines with circular endpoints: 'growth periods' analyzed in Fig. 6

over selected time periods, at least 1 mo in length (see Figs. 3-5 for time periods included in this analysis). This analysis did not show a significant relationship between $\mathrm{C}$ produced $\mathrm{d}^{-1}$ as eggs and change in female $\mathrm{C} \mathrm{d}^{-1}$ for $\mathrm{SB}$ animals $\left(\mathrm{r}^{2}=0.03\right)$. The relationship for the HB animals appeared to be more robust $\left(r^{2}=0.35\right)$, but was driven quite strongly by a single time period from female HB6, which had very high egg production and substantial shrinkage in length. When combined, the relationship for the time periods for all females explains only $11 \%$ of the variability between female growth and egg production (Fig. 6). Females appear slightly more likely to shrink during periods of reproduction, but there is no clear maximum level of egg production at which somatic growth is not possible. Thus, somatic growth and egg production are not tightly coupled.

\section{Reproductive effort}

Reproductive effort, defined as percent of body weight produced as eggs $\mathrm{d}^{-1}$ or brood ${ }^{-1}$, ranged from 0.4 to $2.6 \% \mathrm{~d}^{-1}$ for SB females, and from 0.3 to $5.2 \% \mathrm{~d}^{-1}$ for HB females (Table 1). Two HB females, HB6 and HB7, laid at least twice as many eggs brood ${ }^{-1}$ as other females in this group, producing on average 4.4 and $5.2 \%$ of their body weight $\mathrm{d}^{-1}$ as eggs. 


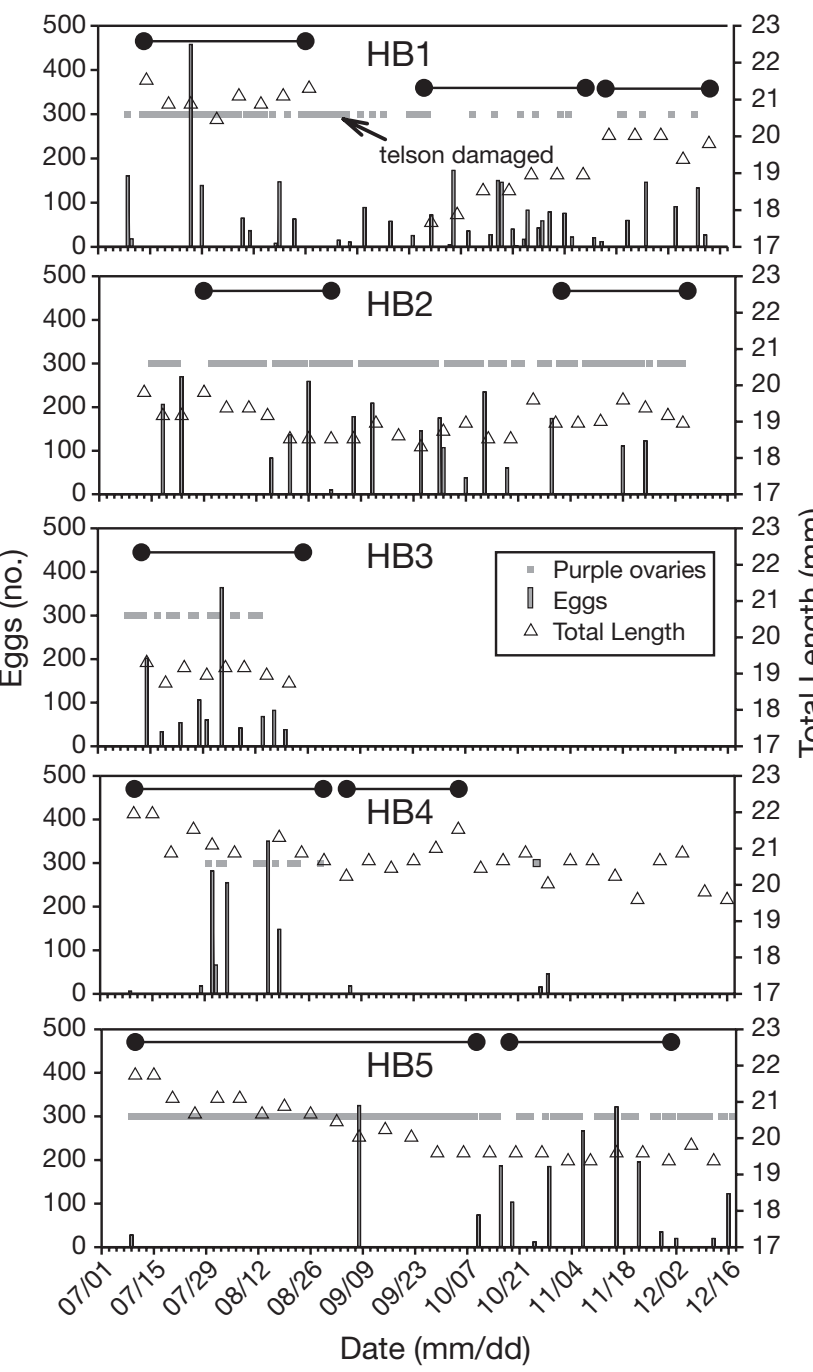

Fig. 4. Euphausia pacifica. Spawning and growth of typical individual HB females. Vertical bars: date and size of each brood of eggs. Triangles: total length (TL) of the female each time she molted. Absence of triangles indicates death of the female before the end of the experiment. Gray horizontal bars indicate when the ovary showed purple coloration. Black lines with circular endpoints: 'growth periods' analyzed in Fig. 6. HB1 had damage to her telson and, although she molted regularly, was unmeasurable between 28 August and 28 September

When calculated as percent female body weight comprising a brood (Fig. 7), the range was 1 to $32.5 \%$ for SB females and 1 to $26 \%$ for HB females, excluding 1 female, HB7, which produced an average of $45.1 \%$ of body weight as eggs brood ${ }^{-1}$ in her 4 broods (range: 2 to $68 \%$ ). The average percent female $\mathrm{C}$ brood $^{-1}$ ranged from 7 to $9 \%$ for SB females and 6 to $45 \%$ for $\mathrm{HB}$ females (Table 1). Most broods from both groups represented less than $15 \%$ of the female's C (Fig. 7). A Mann-Whitney $U$-test of the 2 groups showed no significant difference between females from $\mathrm{SB}$ and $\mathrm{HB}$ in the percent of $\mathrm{C}$ committed to each brood.

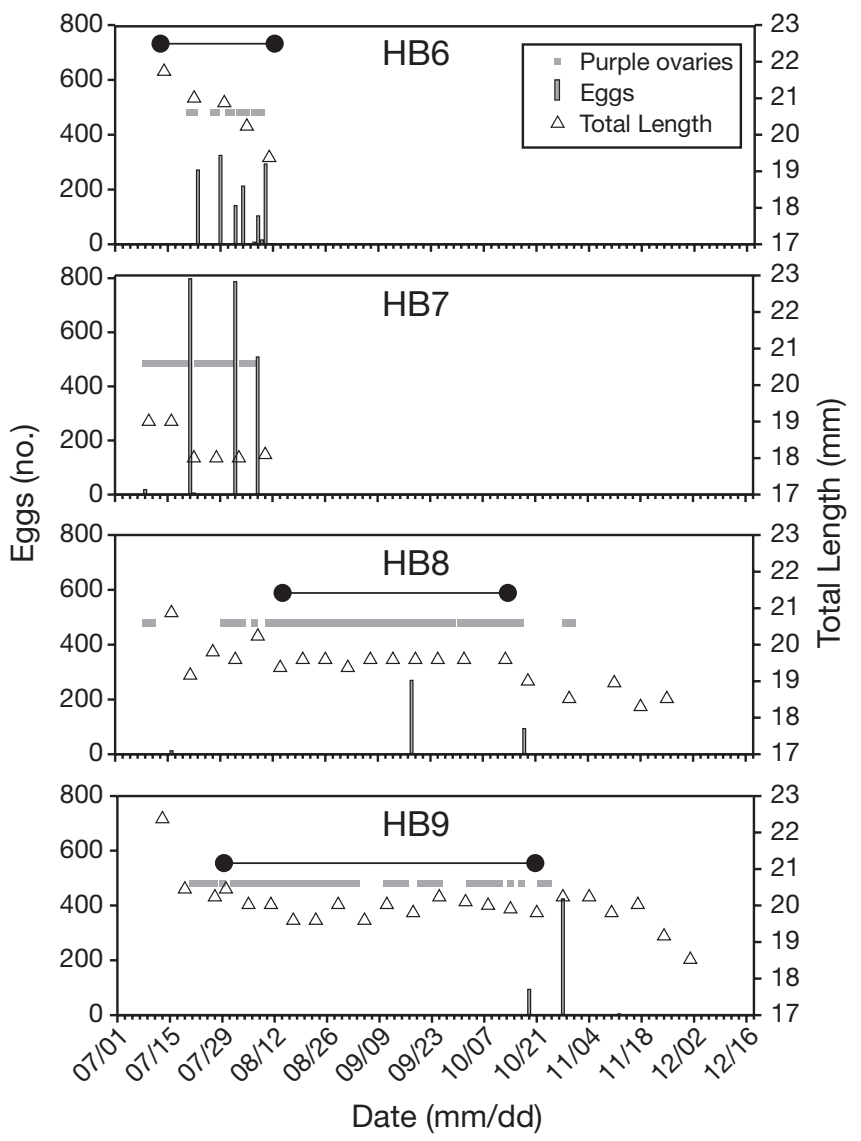

Fig. 5. Euphausia pacifica. Spawning and growth of individual HB females (extreme cases). Vertical bars: date and size of each brood of eggs. Note that the scale of the $y$-axis for brood size extends to 800 in these plots. Triangles: total length (TL) of the female each time she molted. Absence of triangles indicates death of the female before the end of the experiment. Gray horizontal bars indicate when the ovary showed purple coloration. Black lines with circular endpoints: 'growth periods' analyzed in Fig. 6

\section{DISCUSSION}

Our results confirm the assumption that Euphausia pacifica females can release multiple broods of eggs during 1 spawning season, and that individual females can spawn on a regular basis for a period of at least 9 mo. Our long-term laboratory study also illustrated the extraordinary range of reproductive potential of E. pacifica (up to 800 eggs brood $^{-1}$ ) and the high variability in spawning patterns among and within females under relatively constant environmental conditions. Some females spawned on a regular schedule producing broods of eggs every 3 to $4 \mathrm{~d}$, whereas other females often had gaps of several weeks or months between spawning events. This variability may be even greater for animals in the sea, since temperature and food availability in situ can change dramatically over short temporal and spatial scales in dynamic upwelling regions. 
Table 3. Euphausia pacifica. Co-occurrence of spawning and molting for females from SB and HB. Percent of time that females spawn (b) within $24 \mathrm{~h}$ of molting $(\mathrm{m})$ or molt within $24 \mathrm{~h}$ of spawning

\begin{tabular}{|lcrrrrrr|}
\hline Animal & $\begin{array}{c}\text { Broods } \\
\text { (no.) }\end{array}$ & $\begin{array}{c}\% \mathrm{~b} \\
\text { with } \mathrm{m}\end{array}$ & $\begin{array}{c}\% \\
\text { solo b }\end{array}$ & $\begin{array}{c}\text { Molts } \\
\text { (no.) }\end{array}$ & $\begin{array}{c}\% \mathrm{~m} \\
\text { with b }\end{array}$ & $\begin{array}{c}\% \\
\text { solo } \mathrm{m}\end{array}$ & $\mathrm{m}: \mathrm{b}$ \\
\hline SB1 & 64 & 58 & 42 & 43 & 86 & 14 & 0.7 \\
SB2 & 40 & 55 & 45 & 38 & 58 & 42 & 1 \\
SB3 & 34 & 71 & 29 & 42 & 57 & 43 & 1.2 \\
SB4 & 17 & 71 & 29 & 39 & 33 & 67 & 2.3 \\
SB5 & 12 & 67 & 33 & 39 & 20 & 80 & 3.3 \\
HB1 & 30 & 27 & 73 & 24 & 33 & 67 & 0.8 \\
HB2 & 16 & 100 & 0 & 25 & 64 & 36 & 1.6 \\
HB3 & 10 & 80 & 20 & 8 & 100 & 0 & 0.8 \\
HB4 & 9 & 56 & 44 & 28 & 14 & 86 & 3.1 \\
HB5 & 14 & 43 & 57 & 25 & 24 & 76 & 1.8 \\
HB7 & 4 & 75 & 25 & 5 & 60 & 40 & 1.3 \\
HB6 & 6 & 50 & 50 & 4 & 75 & 25 & 0.7 \\
HB8 & 3 & 100 & 0 & 20 & 15 & 85 & 6.7 \\
HB9 & 3 & 33 & 67 & 23 & 4 & 96 & 7.7 \\
HB10 & 4 & 25 & 75 & 4 & 25 & 75 & 1 \\
HB11 & 6 & 67 & 33 & 5 & 80 & 20 & 0.8 \\
\hline
\end{tabular}

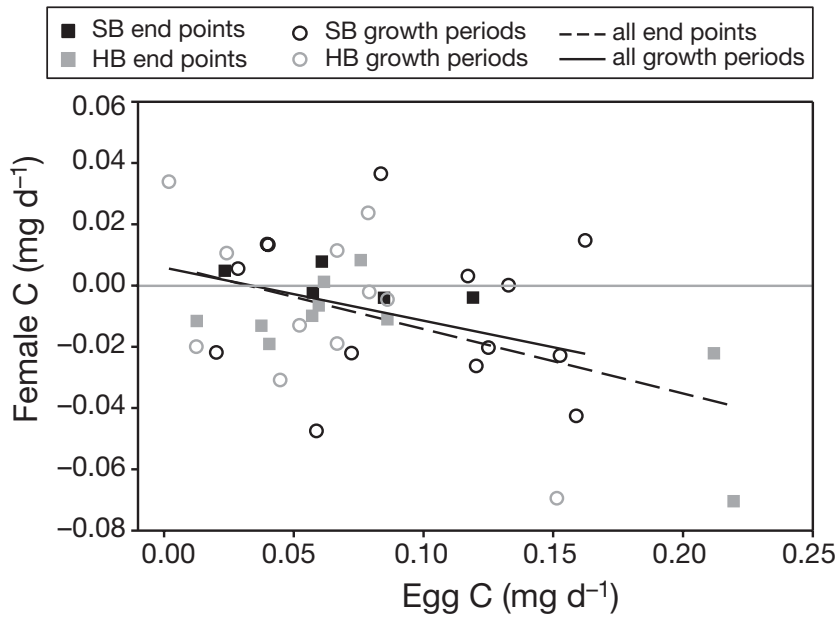

Fig. 6. Euphausia pacifica. Relationship between somatic growth and egg production for females from SB and HB. 'End points': beginning to end of each female's reproductive period. Growth time periods are those depicted in Figs. 3-5. Dashed line: linear regression for all endpoints from both groups, $y=-0.211 x+0.007, r^{2}=0.46$. Solid line: linear regression for all growth time periods from both groups, $y=-0.174 x+0.006, r^{2}=0.11$

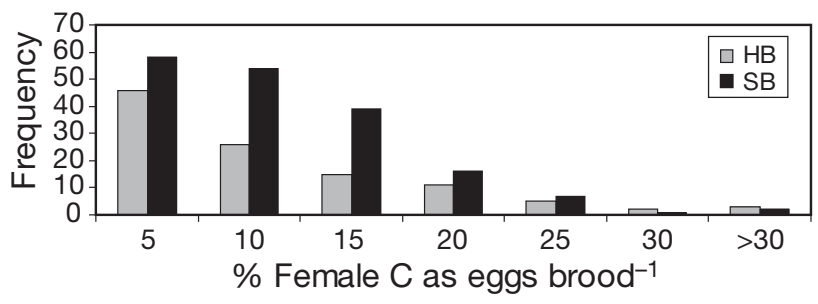

Fig. 7. Euphausia pacifica. Percent carbon released as eggs brood $^{-1}$. No significant differences were found between SB and HB females

\section{Brood size and interbrood period}

The overall range and frequency distribution of brood sizes was comparable to previous measurements from in situ incubations of females of similar length (up to 600 eggs brood $^{-1}$, mean 152 eggs brood ${ }^{-1}$; GómezGutiérrez et al. 2006). Our laboratory observations of brood sizes (medians = 102 for $\mathrm{HB}$ and 116 for $\mathrm{SB}$ ) were similar to those found by Ross et al. (1982; 96 eggs brood ${ }^{-1}$ ), Iguchi \& Ikeda $\left(1994 ; 113\right.$ eggs brood $\left.{ }^{-1}\right)$, and Pinchuk \& Hopcroft (2006; 102 eggs brood $^{-1}$ ), although none of these studies ever observed broods of greater than 300 eggs. Overall, broods in our study were similar to Brinton's (1976) estimates for females of similar lengths, obtained by counting ripe eggs in the ovaries of female Euphausia pacifica off southern California (average of $\sim 150$ ripe eggs female ${ }^{-1}$ ), but the maximum number of ripe eggs ovary ${ }^{-1}$ in that study was only 350 for females of $20 \mathrm{~mm}$ TL. Perhaps southern California animals have smaller maximum brood sizes since they spawn year-round; alternatively, enumeration of the number of ripe eggs in the ovaries may underestimate potential brood size.

\section{Seasonal fecundity estimates}

Although brood sizes were not significantly different between SB and HB females, and IBP only varied by $1 \mathrm{~d}$, there may be substantial differences between the 2 groups in terms of seasonal fecundity. A typical spawning season off the Oregon coast is approximately 6 mo, from mid-March through mid-September (Feinberg \& Peterson 2003). Using this period (184 d), and the median brood size (102 eggs) and IBP (5 d) for HB animals, we calculate a seasonal fecundity of 3754 eggs female ${ }^{-1}$. We do not have good estimates for the spawning season off Santa Barbara, but we assume that it is similar to, or longer than, off Oregon since Euphausia pacifica in the Southern California Bight spawn throughout the year (Brinton 1976). However, if we use the same season length as HB for our calculation of SB seasonal fecundity, along with their median brood size (116 eggs) and IBP (4 d), the result is a seasonal fecundity of at least 5336 eggs female ${ }^{-1}$ for the SB animals. Thus, seasonal fecundity of populations separated by $10^{\circ}$ of latitude can vary by at least $30 \%$.

Pinchuk \& Hopcroft (2006) and Ross et al. (1982) both calculated potential IBPs and seasonal fecundities for Euphausia pacifica. The spawning seasons in their study areas, 3 to 4 mo (northern Gulf of Alaska, 
Pinchuk \& Hopcroft 2006) and 1 to 2 mo (Puget Sound, Washington, Ross et al. 1982) were substantially shorter than those in our study. In experiments very similar to ours, Pinchuk \& Hopcroft (2006) reported a maximum seasonal fecundity of 1530 eggs female ${ }^{-1}$. Though substantially lower than the seasonal fecundity calculated in the present study, their median IBP of $5 \mathrm{~d}$ (A. Pinchuk pers. comm.) and average brood size (102 eggs) are nearly identical to females from both Oregon and California. Thus, the difference in seasonal fecundity appears to be primarily due to a shorter breeding season for E. pacifica in the Gulf of Alaska.

Ross et al. (1982) calculated IBPs from the inverse proportion of females with ovaries that turned purple and produced a brood within $24 \mathrm{~h}$ of being incubated. This method assumes that all females are reproductively active and that spawning is not synchronous. Using IBPs derived in this manner, they calculated maximum seasonal fecundities that ranged from 1000 to 3700 eggs female $^{-1}$, depending on the size of the female. These seasonal fecundities are lower than our study, but only because of the shorter spawning season in Puget Sound. Given a spawning season of similar length to Oregon (similar latitude, but very different environmental conditions), brood size estimates from Ross et al. (1982) would far exceed those of open ocean populations. The IBPs used for the calculations were approximately 2 to $3 \mathrm{~d}$, much shorter than the estimates of Pinchuk \& Hopcroft (2006) or our study. This leads us to question whether spawning behavior is significantly different in Puget Sound or whether some of the assumptions for their methods might have been unfounded. If the IBPs for the Puget Sound population were incorrect, and the 'true' IBPs are similar to those measured in the other studies, then the estimates of seasonal fecundity for Puget Sound could be approximately half of the reported values. This problem can only be resolved by carrying out a study such as ours for animals collected from several sites within Puget Sound, Washington.

\section{Connection between spawning and purple ovaries}

We reject the assumption that females will always spawn within 24 to $48 \mathrm{~h}$ of turning purple. Some females in this study repeatedly retained purple ovaries for many days without spawning (Figs. 3-5). It is possible that prolonged incubation in 11 jars altered the propensity for females to spawn, but it is unlikely that this is purely an artifact of prolonged laboratory incubation, because in much shorter in situ experiments (Gómez-Gutiérrez et al. 2006), purple females did not lay eggs within $48 \mathrm{~h} \sim 25 \%$ of the time. Since purple coloration of the ovaries by itself is not a reliable predictor of imminent spawning, further study of the ovaries and egg maturity would be important in order to isolate some other predictor of a forthcoming spawning event. If we could determine IBP from some static measure related to ovary maturity, we might be able to calculate fecundity from preserved euphausiid samples.

\section{Spawning patterns}

The variability that we observed in spawning behavior was striking. Lack of a common spawning pattern among females makes it difficult to produce generalizations, especially given that we have long-term data for only a small number of females $(\mathrm{n}=14)$ under laboratory conditions. However, since all of our observations were made under the same temperature, light, and feeding conditions, for periods of time ranging from 1 to $9 \mathrm{mo}$, we suggest that the variation observed in spawning must be due to inherent strategic differences among females, rather than a response to physical or physiological conditions. Moreover, the range in variations which we observed leads us to suggest that this species has a very plastic reproductive strategy, and that although we may not have captured the complete range of variability in egg production rate, our 14 examples certainly illustrate that the range in variability is very high in both populations studied. The high degree of variability in spawning patterns expressed by Euphausia pacifica likely contributes to their broad ecological success.

One potential source of variation in egg production might be related to the environment of females at the time of collection. We tried to minimize this problem through the following actions: both collection sites were within the zones of active coastal upwelling, animals were collected at about the same time in the seasonal upwelling cycle, and both sea surface temperature (SST) and chlorophyll concentrations at the time of collection were similar. SB animals were collected in April 2003, when SST was 13 to $14^{\circ} \mathrm{C}$ (www.icess.ucsb.edu), and April is typically the time when the spring phytoplankton bloom appears in these waters (Venrick 1998). HB animals were collected in July 2003, when SST was $11.9^{\circ} \mathrm{C}$ and surface chlorophyll was $6.5 \mu \mathrm{g} \mathrm{l}^{-1}$, and July is the month of maximum chlorophyll concentrations (Feinberg \& Peterson 2003). By collecting animals from similar environments, we hoped that we could minimize potential differences in the patterns of spawning, but we cannot be certain.

Another potential source of variation in egg production is female age. However, since it is not possible to determine the age of the females without sacrificing them, we cannot evaluate this hypothesis. Cohort analysis of preserved samples of Euphausia pacifica 
collected off Oregon (Smiles \& Pearcy 1971) and southern California (Brinton 1976) suggested that animals of the size which we used in our experiments (18 to $21 \mathrm{~mm}$ ) were approximately $1 \mathrm{yr}$ of age, and that animals $>22 \mathrm{~mm}$ might be $2 \mathrm{yr}$ old. Based on the same publications, it is reasonable to assume that the SB animals could have been born the previous spring and the $\mathrm{HB}$ animals in the previous summer. Due to the ability of E. pacifica to shrink as well as grow, some females could have been older (or younger) than assumed. Thus it is possible that there is an association between female age and brood size, but we were not able to test this hypothesis in the current study.

Can we estimate the true lifetime fecundity of Euphausia pacifica from our experiments? Clearly, females are capable of producing eggs on a regular basis for 6 to $9 \mathrm{mo}$, as shown by 7 of the 14 females (Figs. 3-5). The maximum for HB females was 2522 eggs in 6 mo and 8597 eggs female ${ }^{-1}$ for SB females over 9 mo (Table 1). If we assume that those females which produced less than the maxima (and survived for the entire experiment: e.g. females SB3, SB4, SB5 and HB4, HB8, HB9) did so due to some age-related or other unknown physiological condition limiting their reproductive output, we might view their fecundity as an underestimate. Thus, assuming that E. pacifica females spawn primarily in one season (Ross \& Quetin 2000), we tentatively suggest that the true fecundity of these animals ranges from 2500 to 8600 eggs female ${ }^{-1}$ lifetime $^{-1}$.

\section{Comparison to the Benguela upwelling system}

We patterned our work after Stuart (1992), who documented the ability of Euphausia lucens to produce multiple broods in the laboratory. In her experiments, 5 females spawned multiple times and 2 females spawned almost continuously (mean IBP $=2 \mathrm{~d}$ ) for a period of $2.5 \mathrm{mo}$. Egg production ranged from 0 to 86 eggs $\mathrm{d}^{-1}$ for the 2 continuous spawners. Assuming a 9 mo spawning season, Stuart (1992) calculated that an average female could spawn 6345 eggs season ${ }^{-1}$. Though we often found higher brood sizes for E. pacifica, our IBP was usually much longer. Thus, the total number of eggs season ${ }^{-1}$ ended up being of similar magnitude between these 2 studies. Despite a small sample size and slightly smaller animals (14-16 mm), her study is a useful comparison to our results due to the similarly prominent role played by the euphausiids in a dynamic upwelling system.

Euphausia lucens females released an average of 3 to $4 \%$ of their body $\mathrm{C}$ as eggs each day (Stuart 1992), although within the range seen in our experiments ( 0.3 to $5.2 \%)$ it was still higher than seen for most of our females. However, 1 of our experimental females, SB1, showed a similar spawning pattern (Fig. 3) to the females described by Stuart (1992) and also released $\sim 3 \%$ of her $\mathrm{C}$ weight as eggs $\mathrm{d}^{-1}$ (Table 1 ). Perhaps with larger sample sizes, we would find that the nearly continuous spawning cycle is 1 of many strategies employed by both species and that a 3 to $4 \% \mathrm{C}$ investment in eggs $\mathrm{d}^{-1}$ is typical of that pattern.

\section{Relationship between spawning and molting}

Stuart (1992) found for Euphausia lucens that egg production was often lower on the days that the females molted. The E. lucens females molted approximately every $4 \mathrm{~d}$ and had an average IBP of $2 \mathrm{~d}$. We did not see the same relationship between egg production and molting (Figs. 3-5, Table 3). This is not unexpected because our longer IBPs and inter-molt periods ( $6 \mathrm{~d}$ ) resulted in less likelihood of simultaneous occurrence of these 2 functions. Cuzin-Roudy \& Buchholz (1999) suggested a strong relationship between spawning and the molt cycle for several populations of Meganyctiphanes norvegica. They suggested that spawning coincides with molt preparation (apolysis and D1, when the new setae begin to form tubule structures within the epidermis) and that spawning-molt cycles alternate with vitellogenic-molt cycles (Cuzin-Roudy \& Buchholz 1999). In other words, spawning should occur near the middle of every other molt cycle. We could not stage the ovaries of our females or document the progression of their molt cycles without killing them, but the data in Figs. 3 to 5 clearly suggest that E. pacifica does not dedicate every other molt cycle only to vitellogenesis. It is impossible to know for sure from our study whether spawning coincides with particular stages of the molt cycle, but we conclude that it is unlikely given the inconsistency in the spawning and molting relationship (Table 3).

\section{Relationship between spawning and growth}

In situ growth rates calculated from lengths of 18 to $21 \mathrm{~mm}$ adult female Euphausia pacifica from the northeast Pacific range from -0.15 to $0.15 \mathrm{mg} \mathrm{C} \mathrm{d}^{-1}$ with an average of $0.01 \mathrm{mg} \mathrm{C} \mathrm{d}^{-1}$ (Pinchuk \& Hopcraft 2007, C. Shaw unpubl. data). In contrast, in the present study, we never saw growth rates greater than $0.04 \mathrm{mg} \mathrm{C} \mathrm{d}^{-1}$ and more often than not we observed negative growth. The growth rates in our experiment are commonly seen in field experiments (although our range was narrower overall) and tended to be slower than the general population of females represented in our own field experiments and those reported by others. The difference 
could be attributed to energy invested in egg production. It is also possible that length does not perfectly capture the changes in weight experienced by spawning females. There was always a slight negative relationship between egg production and somatic growth (Fig. 6), suggesting that increased egg production decreases somatic female growth, but even more striking is the variability. While it was rare for females to be growing quickly while producing large quantities of eggs, every other combination of growth and egg production was common (Fig. 6). If we were to pick a level of egg production that appears to thwart somatic growth, it would be $\geq 0.17 \mathrm{mg} \mathrm{C} \mathrm{d}^{-1}$ produced as eggs (Fig. 6). This is equivalent to a daily egg production rate of 53 eggs female $^{-1}$. No SB females had rates that high, and only $2 \mathrm{HB}$ females (HB7 and HB11, Table 1) produced eggs at that approximate rate. Females HB7 and HB11 both died about 1 mo into the experiment, suggesting that this rate of egg production may not be sustainable over the long term.

Broods from both groups averaged $9 \%$ of female body C, although 1 short-lived 'overachiever' (HB7) averaged $45.1 \%$ brood $^{-1}$ (Table 1). Assuming a gross growth efficiency of 0.22 (calculated from Ross 1982a, b), most of the females in this experiment had to consume from 1.8 to $11.8 \%$ of their body weight $\mathrm{d}^{-1}(\mathrm{SB})$ and 1.4 to $10.9 \%$ of their body weight $\mathrm{d}^{-1}(\mathrm{HB})$, with females HB6 and HB7 consuming over $20 \%$ of their body weight $\mathrm{d}^{-1}$. This range in ingestion rates is quite similar to that reported by Ohman (1984), who found a maximum ingestion rate of $\sim 8 \%$ body $\mathrm{C} \mathrm{d}^{-1}$ at a cell concentration of $200 \mathrm{\mu g} \mathrm{Cl}^{-1}$. Given this level of reproductive effort and ingestion, it should not be surprising that female growth during this experiment was minimal. In fact, most females got smaller during at least 1 portion of the experiment (Table 2, Figs. 3-5), despite being maintained at consistently high food concentrations of $\sim 500 \mu \mathrm{g} \mathrm{Cl}^{-1}$, nearly twice the concentration used by Ohman (1984).

Ross (1982b) found that egg production could account for approximately $50 \%$ of C that adult Euphausia pacifica committed to somatic growth + reproduction + molting. In contrast, we found that females allocated far more of their assimilated energy to egg production than to somatic growth (Tables $1 \& 2$ ). The difference between Ross (1982b) and our work may be attributed to the fact that females in her experiments were small, 0.7 to $3.0 \mathrm{mg}$, and likely younger, all less than $1 \mathrm{yr}$ old. Young E. pacifica adults that have not yet reached their full adult size grow at a faster rate than larger adults (Smiles \& Pearcy 1971, Brinton 1976) and might tend to allocate more energy to somatic growth than to reproduction. Brinton (1976) found that the number of ripe eggs carried in the ovary of mature females increased with size from $11 \mathrm{~mm}$ and 25 mature eggs in the ovaries up to $20 \mathrm{~mm}(\sim 5.4 \mathrm{mg} \mathrm{C})$ and 220 mature eggs in the ovaries, suggesting a benefit to allocating more energy toward growth in small females in order to reach a larger size and thus maximize reproductive output (as seen in larger females). The females in our study ranged in size from 3.8 to $6.5 \mathrm{mg} \mathrm{C}$, and while they invested 25 to $600 \%$ of their body C into egg production over the course of the incubations (Table 1), 73\% of them decreased in size during this same time period.

We suggest that during the spawning season, Euphausia pacifica may allocate energy to growth, egg production, or a combination of both. Females increased and decreased in size throughout the experiment, with an overall decrease in size for most females. They also did not produce broods of the same size every time they spawned, suggesting that individual adult females vary as to how they allocate their resources to egg production or to somatic growth. Maintaining a balance between somatic growth and egg production may be the factor that leads to variability in brood sizes from the same female.

\section{CONCLUSIONS}

Euphausia pacifica produced multiple broods during the 6 to 9 mo duration of this experiment. They did not always release eggs imminently when the ovaries showed a purple coloration, suggesting that ovary ripeness or frequency of females with purple ovaries should not be used as a means to calculate IBP. There was no significant difference in brood size between females from Santa Barbara, California, and Heceta Bank, Oregon, but IBP was $1 \mathrm{~d}$ shorter for females from SB. E. pacifica is capable of producing broods far larger (up to 800 eggs) and more frequently (up to every other day) than previously assumed. E. pacifica females may be able to produce more than 5000 eggs season ${ }^{-1}$, and at this rate of egg production, females are likely to decrease in size. Spawning patterns were extremely variable, even for individual animals, suggesting that this euphausiid has a highly plastic reproductive strategy.

Our results suggest that the best approach to modeling the population dynamics of Euphausia pacifica is to use individual based models. We suggest this because of the high degree of variability observed under constant laboratory conditions (as shown in this study) and a similarly high degree of variability seen in in situ incubations (Gómez-Gutiérrez et al. 2006). Clearly, the median brood size does not illustrate the 'true' brood size (especially given a common range of 2 to 300 eggs brood $^{-1}$, with broods of 500 to 800 eggs not uncommon). Thus, realistic simulations of the population dynamics of this species will require tracking the growth of individuals. 
Acknowledgements. We thank J. Gómez-Gutiérrez for his dedicated hours in the cold room, his stamina, and for helpful discussions of the data. We thank J. Lamb, M. Vance, R. Hooff, C. Morgan, and J. Menkel for assistance with experiments and J. Keister for establishing the length-weight relationship for Euphausia pacifica females. We appreciate the assistance of S. Gaskill and the Oregon State University Molluscan Broodstock Program in maintaining many of the algal diets used in this study. We thank S. Goldthwait for collection of SB animals. This study was funded by U.S. GLOBEC and is contribution number 518 from the NE Pacific U.S. GLOBEC program.

\section{LITERATURE CITED}

Brinton E (1962) The distribution of Pacific euphausiids. Bull Scripps Inst Oceanogr, Univ Calif 8:51-269

Brinton E (1976) Population biology of Euphausia pacifica off southern California. US Fish Wildl Serv Fish Bull 74: 733-762

Cuzin-Roudy J, Buchholz F (1999) Ovarian development and spawning in relation to the moult cycle in Northern krill, Meganyctiphanes norvegica (Crustacea: Euphausiacea), along a climate gradient. Mar Biol 133:267-281

Feinberg LR, Peterson WT (2003) Variability in duration and intensity of euphausiid spawning off central Oregon, 1996-2001. Prog Oceanogr 57:363-379

Gómez-Gutiérrez J (2003) The population dynamics, secondary productivity, and reproductive ecology of the euphausiids Euphausia pacifica and Thysanoessa spinifera in the Oregon upwelling region. PhD dissertation, Oregon State University, Corvallis

Gómez-Gutiérrez J, Feinberg LR, Shaw T, Peterson WT (2006) Variability of brood size and female length of Euphausia pacifica among three populations in the North Pacific. Mar Ecol Prog Ser 323:185-194

Iguchi N, Ikeda T (1994) Experimental study on brood size, egg hatchability, and early development of a euphausiid Euphausia pacifica from Toyama Bay, Southern Japan Sea. Bull Jpn Sea Natl Res Inst 44:49-57

Iguchi N, Ikeda T (1998) Elemental composition (C, H, N) of the euphausiid Euphausia pacifica in Toyama Bay, southern Japan Sea. Plankton Biol Ecol 45:79-84

Editorial responsibility: Steven Morgan (Contributing Editor), Bodega Bay, California, USA
Lasker R (1966) Feeding, growth respiration and carbon utilization of a euphausiid crustacean. J Fish Res Board Can 23: 1291-1317

Matthiessen GC, Toner RC (1966) Possible methods of improving the shellfish industry of Martha's Vineyard, Duke's County, Massachusetts. Mar Res Found, Edgartown, MA

Mauchline J, Fisher LR (1969) The biology of euphausiids. Adv Mar Biol 7:1-454

Ohman M (1984) Omnivory by Euphausia pacifica: the role of copepod prey. Mar Ecol Prog Ser 19:125-131

Pinchuk AI, Hopcroft RR (2006) Egg production and early development of Thysanoessa inermis and Euphausia pacifica (Crustacea: Euphausiacea) in the northern Gulf of Alaska. J Exp Mar Biol Ecol 332:206-215

Pinchuk AI, Hopcroft RR (2007) Seasonal variations in the growth rates of euphausiids (Thysanoessa inermis, $T$. spinifera, and Euphausia pacifica) from the northern Gulf of Alaska. Mar Biol 151:257-269

Ponomareva LA (1966) Euphausiids of the North Pacific, their distribution and ecology. (Translation of a 1963 paper). Israel Program of Scientific Translations, Jerusalem

Ross R (1982a) Energetics of Euphausia pacifica I. Effects of body carbon and nitrogen and temperature on measured and predicted production. Mar Biol 68:1-13

Ross R (1982b) Energetics of Euphausia pacifica II. Complete carbon and nitrogen budgets at $8^{\circ}$ and $12^{\circ} \mathrm{C}$ throughout the lifespan. Mar Biol 68:15-23

Ross RM, Quetin LB (2000) Reproduction in Euphausiacea. In: Everson I (ed) Krill biology, ecology and fisheries. Blackwell Publishing, Oxford, p 150-181

Ross RM, Daly KL, English TS (1982) Reproductive cycle and fecundity of Euphausia pacifica in Puget Sound, Washington. Limnol Oceanogr 27:304-314

Smiles MC, Pearcy WG (1971) Size, structure and growth of Euphausia pacifica off the Oregon coast. US Fish Wildl Serv Fish Bull 69:79-86

Stuart V (1992) Fecundity of Euphausia lucens (Hansen): laboratory evidence for multiple broods. J Exp Mar Biol Ecol 160:221-228

Venrick EL (1998) The phytoplankton of the Santa Barbara basin: patterns of chlorophyll and species structure and their relationships with those of surrounding stations. Calif Coop Ocean Fish Invest Rep 39:124-132

Submitted: September 13, 2006; Accepted: March 2, 2007 Proofs received from author(s): June 16, 2007 